\title{
Artvin'i Ziyaret Eden Turistlerin Gastronomi Deneyimleri Üzerine Bir Inceleme*
}

\author{
Yener Oğan ${ }^{* *}$ iD Fügen Durlu Özkaya ${ }^{2}$ \\ ${ }^{1}$ Artvin Çoruh Üniversitesi, Uygulamalı Bilimler Yüksekokulu, Artvin, Türkiye, oganyener@gmail.com, ORCID: 0000-0002-1523-8498 \\ ${ }^{2}$ Ankara Hacı Bayram Veli Üniversitesi, Turizm Fakültesi, Ankara, Türkiye, fugen.ozkaya@hbv.edu.tr, ORCID: 0000-0003-2893-9557
}

Öz

Araştırma Makalesi

Turistler bir yöreye özgü yemekleri tatmak, mutfak kültürünü tanımak, yemeklerin üretim metotlarını görmek için turizm faaliyetlerine katılabilmektedir. Doğal ve kültürel turizm kaynakları ile Artvin, Türkiye'nin önemli turizm şehirleri arasında yer almaktadır. Bu araştırma Artvin ilinde yiyecek içecek hizmeti satın alan turistlerin Artvin gastronomisi deneyimleri ile ilgili görüşlerini incelemek amacıyla yapılmıştır. Araştırmada veriler Artvin'i ziyaret eden 400 turiste anket formu kullanılarak elde edilmiştir. Elde edilen veriler doğrultusunda turistlerin demografik bilgileri ve gastronomi deneyimleri ile ilgili t-testi ve Anova testlerine ilişkin istatistiki değerlere yer verilmektedir. Araştırmada yöreyi ziyaret eden turistlerin Artvin gastronomisi ile ilgili genel olarak olumlu görüşleri olduğu sonuçlarına ulaşılmıştır. Turistlerin gastronomi deneyimleri ile cinsiyetleri, uyrukları, yaşları, medeni durumları, eğitim durumu, meslekleri, Artvin'i tercih etme nedenleri arasında anlamlı ilişkiler bulunmakta iken gelir seviyesi ve Artvin yemeklerini beğenme durumları arasında ise anlamlı bir ilişkiye rastlanılmamıştır. Ayrıca araştırma kapsamında bazı önerilere yer verilmektedir.

Anahtar Kelimeler: Artvin, Turizm, Turistler, Gastronomi Deneyimi

\section{An Investigation on the Gastronomy Experiences of Tourists Visiting Artvin}

Abstract

Tourists have been participating in tourism activities in order to taste the dishes specific, to get to know the culinary culture, and to see the production methods of the dishes to a region. Artvin having natural and cultural tourism resources, it is among the important tourism cities of Turkey. This research was carried out to examine the opinions of tourists who buy food and beverage services in Artvin about their Artvin gastronomy experiences. In the research, the data were obtained by using a survey form for 400 tourists visiting Artvin. In direction with the data obtained, T-test and Anova tests related to the demographic information and gastronomic experiences of the tourists are included. In the research, it was concluded that the tourists visiting the region have generally positive opinions about Artvin gastronomy. While there are significant relationships between the gastronomy experiences of tourists and their gender, nationality, age, marital status, educational status, professions, reasons for choosing Artvin, there is no significant relationship was found between the income level and their liking of Artvin food. In addition, some suggestions are included within the scope of the research.

Keywords: Artvin, Tourism, Tourists, Gastronomy Experience
Cilt 5, Sayı 2, 2021

ss. $211-227$

Gönderim : 19.02.2021

1. Düzeltme: 31.05 .2021

2. Düzeltme: 13.06 .2021

3. Düzeltme: 02.08 .2021

Kabul Tarihi: 04.08.2021

Research Article

Vol 5, No 2, 2021

pp. $211-227$

Received: 19.02 .2021

Revision1: 31.05.2021

Revision2: 13.06.2021

Revision3: 02.08.2021

Accepted: 04.08.2021

\section{Önerilen Atıf/Suggested Citation}

Oğan, Y. ve Durlu Özkaya, F. (2021). Artvin'i Ziyaret Eden Turistlerin Gastronomi Deneyimleri Üzerine Bir İnceleme. Güncel Turizm Araştırmaları Dergisi, 5(2), 211-227.

*Bu çalışma, Ankara Hacı Bayram Veli Üniversitesi / Lisansüstü Eğitim Enstitüsü/Gastronomi ve Mutfak Sanatları Ana Bilim Dalında "Artvin ilinin Gastronomi Değerleri; Yiyecek Içecek Hizmeti Sunan Işsletmeler ve Satın Alan Turistler Üzerine Bir Inceleme" adlı doktora tezinden üretilmiştir.

**Sorumlu yazar e-posta: oganyener@gmail.com 


\section{GíRiş}

Coğrafi konum, iklim, inanç, tarımsal üretim, sosyo-ekonomik yapı, beslenme şekli, yaşam tarzı gibi pek çok unsur yöresel mutfakların temel belirleyicisi olabilmektedir (Beşirli, 2010). Günümüzde bir yöreyle özdeşleşmiş yemekler ve mutfak gelenekleri çeşitli nedenlere bağlı olarak bilinirlik düzeyleri artmaktadır. Bu nedenlerden bazıları ise sağlıklı, çevreye duyarlı, taze gıdalara yönelik talebin artması ve bir yörenin mutfağını keşfetmek için gerçek bir ilginin var olması şeklinde ifade etmek mümkündür (Getz, 2000). Turizm faaliyetlerine yön veren ve turizm hareketlerinin belirleyicisi durumunda olan turistler, bir turizm ürününü satın almanın ötesinde satın alınan ürün ile ilgili bir deneyim arayışı içerisinde olduğu görülmektedir (Morgan vd., 2010; Eryılmaz ve Zengin, 2014). Son yıllarda turistler, gastronomi turizmi çerçevesinde bir yöreye özgü yemekleri tadabilmek veya yeme-içme kültürünü tanıyabilmek için destinasyonları ziyaret etmede önemli bir motivasyon faktörü olabilmektedir (Yüncü, 2010; Serçek, 2018). Örneğin Kesici (2012) kirsal turizme olan talepte yöresel yiyecek ve içecek kültürünün rolü başlıklı çalışmasında gastronomi turizmine katılan turistlerin büyük bir bölümü tercih ettiği destinasyondan yiyecek, içecek, yemek tarifi, şarap vb. ürünleri sürekli ikamet ettikleri yerlere götürme ve bu ürünleri yakın çevresi ile paylaşma eğiliminde olduğunu belirtmiştir. Bu durum bir yöreyi ziyaret eden turistlerin yörenin tanıtımı ve ekonomisi için son derece önemli olduğu şeklinde ifade edilebilmektedir.

Turistlerin yöresel gastronomi deneyimi mutfak kültürlerini tanımak ve öğrenmek için önemli bir fırsat oluşturmaktadır. Türkiye sahip olduğu binlerce yıllık köklü geçmişi, zengin mutfağı ve turistik çekiciliği ile gastronomi turizmi için dünyada tercih edilen önemli bir ülke olma özelliği taşımaktadır. Türkiye'de bulunan Gaziantep, Hatay ve Afyonkarahisar illerinin UNESCO (Birleşmiş Milletler Eğitim, Bilim ve Kültür Örgütü) yaratıcı şehirler ağı kapsamında gastronomi kentleri arasında yer alması da bu durumun en önemli göstergesidir. Yine Türkiye'nin farklı şehirlerinde düzenlenen turizm fuarları, sokak lezzetleri, peynir festivali, lezzet festivali, çikolata-tatlı festivali, ot festivali, vegan festivali, hamsi şenliği, tanıtım günleri gibi etkinlikler gastronomi turizmine önemli katkılar sunmaktadır. Bir yörede gastronomi turizminin gerçekleştiğinin en önemli göstergelerinden biri ise o yörenin gastronomisini deneyim etmek amacıyla gelen turistler oluşturmaktadır.

Günümüzde mutfak kültürlerini tanımaya yönelik seyahatler artmakta ve turizm faaliyetlerine katılan hemen hemen her turist ziyaret ettiği destinasyonun yöresel mutfağını merak etmektedir. Özellikle seyahat işletmelerinin turistlere yönelik planladığ 1 tur programlarında ise gastronomi temalı etkinlikler ilgi çekmekte ve talep görmektedir. Doğal ve kültürel kaynaklarıyla Türkiye'nin önemli bir turizm şehri olan Artvin ili; yöresel ürünleri, yöreye özgü yemekleri, geleneksel ekipmanlar ve pişirme teknikleri, zengin mutfak kültürü ile özel bir gastronomi potansiyeli bulunmaktadır. Araştırma kapsamında Artvin ilindeki gastronomi potansiyeli varlığının keşfedilmesi açısından yöreyi ziyaret eden turistlerin görüşlerinin önemli olduğu düşünülmektedir. Dolayısıyla araştırmanın temel problemini “Artvin ilini ziyaret 
eden turistlerin yöre gastronomisi ile ilgili deneyimlerinin ne olduğu?" oluşturmaktadır. Araştırmada Artvin ilinde yiyecek içecek hizmeti satın alan turistlerin Artvin gastronomisi deneyimleri ile ilgili görüşlerinin incelenmesi amaçlanmaktadır. Bu doğrultuda araştırmanın amacına uygun olarak oluşturulan hipotezler şu şekilde sıralanmaktadır.

$\mathrm{H}_{1}$ : Artvin ilinde yiyecek içecek hizmeti satın alan turistlerin Artvin ili gastronomisi ile ilgili deneyimleri bulunmaktadır.

$\mathrm{H}_{2}$ : Artvin ili gastronomisi deneyimleri ile Artvin ilinde yiyecek içecek hizmeti satın alan turistlerin demografik özellikleri arasında anlamlı bir ilişki vardır.

$\mathrm{H}_{2.1}$ : Artvin ili gastronomisi deneyimleri ile Artvin ilinde yiyecek içecek hizmeti satın alan turistlerin cinsiyetleri arasında anlamlı bir ilişki vardır.

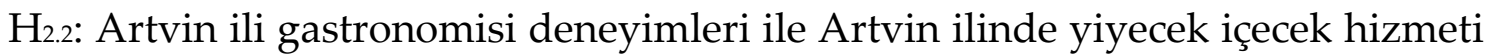
satın alan turistlerin uyrukları arasında anlamlı bir ilişki vardır.

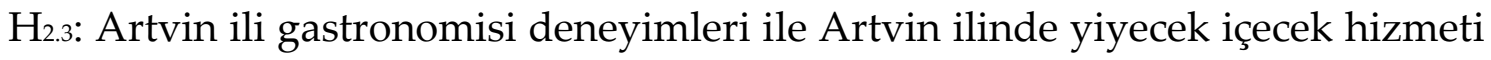
satın alan turistlerin yaşları arasında anlamlı bir ilişki vardır.

$\mathrm{H}_{2.4}$ : Artvin ili gastronomisi deneyimleri ile Artvin ilinde yiyecek içecek hizmeti satın alan turistlerin medeni durumları arasında anlamlı bir ilişki vardır.

$\mathrm{H}_{2.5}$ : Artvin ili gastronomisi deneyimleri ile Artvin ilinde yiyecek içecek hizmeti satın alan turistlerin eğitim durumları arasında anlamlı bir ilişki vardır.

$\mathrm{H}_{2.6}$ : Artvin ili gastronomisi deneyimleri ile Artvin ilinde yiyecek içecek hizmeti satın alan turistlerin meslekleri arasında anlamlı bir ilişki vardır.

$\mathrm{H}_{2.7}$ : Artvin ili gastronomisi deneyimleri ile Artvin ilinde yiyecek içecek hizmeti satın alan turistlerin gelir seviyesi arasında anlamlı bir ilişki vardır.

$\mathrm{H}_{2.8}$ : Artvin ili gastronomisi deneyimleri ile Artvin ilinde yiyecek içecek hizmeti satın alan turistlerin Artvin ili tercihleri arasında anlamlı bir ilişki vardır.

$\mathrm{H}_{2.9}$ : Artvin ili gastronomisi deneyimleri ile Artvin ilinde yiyecek içecek hizmeti satın alan turistlerin yemekleri beğenme durumları arasında anlamlı bir ilişki vardir.

\section{İlgili Araştırmalar}

Işkın (2021) gastronomi turizmine yerli turistlerin katılım durumunu araştırdı̆̆ çalışmasında, yerli turistlerin kültür ve yöresellik temalı gastronomi değerleri deneyimleme motivasyonlarının yüksek düzeyde olduğu sonucuna ulaşmıştır. Akyürek ve Kutukız (2020) gastro turistlerin deneyimlerini inceledikleri çalışmalarında turist deneyimlerinin ürüne, ilişkiye, faaliyete ve ortama dayalı olmak üzere dört farklı temada oluştuğunu tespit etmiştir. Semerci ve Akbaba (2018) Bodrum'da yaptıkları bir çalışmada ziyaretçilerin yöresel yemek tüketimindeki motivasyon kaynağının belirlenmesi ve yöresel yemeklerin turistik çekim unsuru olarak sunulmasına katkı sağlayacağını ifade etmiştir. Chavarria ve Phakdee-Auksorn (2017) turistlerin yiyecek ve içeceklere yönelik tutumlarını ve niyetlerini inceledikleri 
çalışmalarında tutum, öznel normlar, algılanan davranışsal kontrol ve geçmiş deneyimlerin önemli olduğunu belirlemiştir. Ayaz ve Yalı (2017) çalışmalarında kültür turizmi açısından önemli bir destinasyon olan Safranbolu ilçesine gelen yerli turistlerin yöreyi seyahat etme tercihleri ve yöredeki yiyecek içecek beklentileri ile ilgili anlamlı sonuçlara ulaşmıştır. Çapar ve Yenipınar (2016) çalışmalarında, turistlerin destinasyon tercihlerinde yöresel yiyeceklerin kültürel kimliğin önemli bir unsuru olduğunu ve yöresel yiyecekler turizm amaçlı kullanılmasıyla bölgeye olumlu birçok katkı sunabileceğini tespit etmişlerdir. Birdir ve Akgöl (2015) Türkiye' yi ziyaret eden yabancı turistler üzerine yaptıkları çalışmalarında turistlerin Türkiye'yi ziyaret etme sebebi nedenlerinden birisinin Türk mutfağına özgü yemekleri deneyim etmek olduğunu tespit etmiştir. Ayrıca bu deneyimin Türkiye'yi tekrar ziyaret etmeleri açısından en önemli unsurlardan biri olduğunu ifade etmiştir. Canizares ve Guzman (2012) Cordoba'yı ziyaret eden turistler üzerine yaptığı çalışmalarında yöresel mutfağın, turistlerin Cordoba'yı ziyaret etmelerindeki en önemli etkenlerden biri olduğunu tespit etmişlerdir. Chang ve arkadaşları (2010) çalışmalarında turistler seyahatleri sırasında gastronomi davranışlarında farklılıklar göstermekte olduğunu belirlemiştir. Correia ve arkadaşları (2007) çalışmalarında turistlerin destinasyon seçimlerini incelemiştir. Araştırma sonucunda ise yiyecek ve içecek ile ilgili unsurların önemli bir beklenti olduğunu tespit etmişlerdir. Jang ve Feng (2007) turistlerin yiyecek ve içecek ile ilgili memnuniyetlerinin ve yenilik arayışlarının etkilerini araştırdıkları çalışmalarında, yiyecek ve içecek ile ilgili memnuniyetin kısa süre içerisinde gittikleri destinasyonu tekrar ziyaret etme isteğini doğrudan etkilediği gözlemlenmiştir. Buna karşılık yenilik arayışında olan turistlerin orta ve uzun vadede tekrar ziyaret edebileceği sonucuna ulaşmıştır. Kivela ve Crotts (2006) Hong Kong'u ziyaret eden turistler üzerine yaptıkları bir çalışmada turistlerin destinasyon seçimlerinde gastronomi turizminin önemli bir rol oynadığını tespit etmiştir. Ayrıca turistler Hong Kong'u tekrar ziyaret etme isteklerinde yemeklerin lezzetli olması, hijyen-sanitasyon, yiyecek ve içeceklerin çeşitliliği gibi durumların öncelikli olduğu saptanmıştır. Bu çalışma kapsamında ilgili araştırmalar incelendiğinde turistlerin destinasyon tercihlerinde yöresel yemeklerin etkisi, hijyen-sanitasyon tutumları, yiyecek içecek memnuniyet durumları, yöresel gastronomi beklentileri üzerine farklı çalışmalar bulunmasına rağmen Artvin yöresini ziyaret eden turistlerin yöredeki gastronomi deneyimleri üzerine ilgili yazında çalışmalara pek rastlanılmamaktadır. Dolayısıyla araştırmanın ilgili yazına katkı sağlaması ve diğer araştırmalara kaynak oluşturması bakımından önemli olduğu düşünülmektedir.

\section{YÖNTEM}

\section{Araştırmanın Modeli}

Bu araştırmada Artvin ilinde yiyecek içecek hizmeti satın alan turistlerin Artvin gastronomisi deneyimleri ile ilgili görüşlerinin ortaya çıkarılmaya çalışılmıştır. Dolayısıyla araştırmanın uygulama kısmını Artvin ilini ziyaret eden ve yiyecek içecek hizmeti satın alan turistler oluşturmaktadır. Araştırmaya konu olan birey, nesne ya da olayları kendi koşulları içerisinde olduğu gibi tanımlanmaya çalışması ve araştırmada 
geçmişten günümüze var olan bir durumu olduğu gibi betimlenmesi amaçlandığı için tarama modeli yaklaşımı benimsenmektedir (Karasar, 2002).

\section{Evren ve Örneklem}

Artvin ilini ziyaret eden ve yiyecek içecek hizmeti satın alan turistler ile ilgili evreni temsil edecek örneklemin seçilmesinde araştırmanın amacına bağlı olarak herhangi bir şekilde evrenin bir parçasının seçildiği seçkisiz olmayan örnekleme yöntemlerinden rastlantısal örnekleme tekniği kullanılmaktadır (Arlı ve Nazik, 2001). Araştırmanın evrenini oluşturan Artvin ilini ziyaret eden turistler ilgili Türkiye Cumhuriyeti Kültür ve Turizm Bakanlığından alınan verilere göre Artvin ilini 2019 yılı itibariyle 2.360.370 yerli ve yabancı turist ziyaret etmiştir. Artvin ilini ziyaret eden turistler için en az 384 örneklem sayısının 0.05 güven aralığında ve 0.05 örneklem hatası ile evreni temsil edebileceği ifade edilebilmektedir (Yamane, 2001; Yazıcıoğlu ve Erdoğan, 2004).

\section{Verilerin Toplanması}

Araştırmada veriler Artvin ilini ziyaret eden 400 turiste gastronomi deneyimlerini tespit etmek amaciyla anket formu uygulanarak elde edilmiştir. Anket formları uygulanmadan önce güvenilir ve geçerli sonuçlara ulaşabilmek amacıyla Artvin ilini ziyaret eden " 20 " turiste anket formları uygulanarak pilot çalışma yapılmıştır. Pilot çalışmadan sonra anket formlarına son hali araştırmacılar tarafından verilmiştir. Anket formlarının uygulanması ile ilgili Ankara Hacı Bayram Veli Üniversitesi Etik Komisyonundan 16.09.2019 tarih 12 sayılı toplantısında etik açıdan bir sakınca bulunmadığ1 ile ilgili etik kurul izni alınmıştır. Araştırma kapsamına örneklem gruplarından toplanan bu veriler 01.10.2019/01.08.2020 tarihleri arasındaki süreyi kapsamaktadır. Araştırmada kullanılan “Turist Anket Formu” Artvin ilini ziyaret eden yerli ve yabancı turistlerin demografik özelliklerini ve Artvin ili gastronomisi ile ilgili deneyimlerini belirlemek amacıyla Türkçe ve İngilizce olarak oluşturulmuştur. Turistlerin deneyimleri ile ilgili araştırmada kullanılan ölçüt "Turistlerin Destinasyon Seçiminde Yöresel Yemeklerin Rolü: İmir Yarımadası'nı Ziyaret Eden Turistlerin Görüşleri Üzerine Bir Araştırma" başlıklı çalışmadan yararlanılarak oluşturulmuştur (Zağralı ve Akbaba, 2015). Araştırmada kullanılan değerlendirme ölçeğinin iç tutarlılık katsayısı incelenmiş ve yapılan test sonucunda güvenirliliğin (Cronbach's Alpha) $\alpha=0.918$ olduğu belirlenmiştir.

\section{Verilerin Analizi}

Artvin ilini ziyaret eden turistlerin Artvin ili gastronomisi ile ilgili deneyimlerini belirlemek amacıyla turist anket formu ile elde edilen verilerin analizi için SPSS.16 programından (Sosyal Bilimler İçin İstatiksel Analiz Programı) yararlanılarak istatistiksel sonuçlar elde edilmiştir. Verilerin analizinde ilk olarak birbiriyle ilişkili değişkenleri bir araya getirerek az sayıda anlamlı değişkenler ortaya çıkarmak amacıyla tanımlayıcı faktör analizi uygulanmıştır (Büyüköztürk, 2009). Faktör analizi uygunluğu için Bartlett'in Küresellik testi sonuçları anlamlı çıkmış olup, KaiserMeyer-Olkin (KMO) örneklem yeterlilik testi tavsiye edilen değer $(, 921)$ tespit edilerek ölçeğin faktör yapısının 3 boyuta sahip olduğu tespit edilmiştir. Ölçeğinin bu 
boyutlarını turistlerin yöre gastronomisi ile ilgili düşünceleri (1,2,3,4,5,6,7,8), izlenimleri $(9,10,11,12,13,14,17)$ ve tutumları $(15,16,18,19,20)$ oluşturmaktadır. Daha sonra anket formunda yer alan turistlerin demografik özellikleri ve Artvin ilini ziyaret eden turistlerin Artvin gastronomisi deneyimlerine ile ilgili bulgularin yorumlanmasında frekans, yüzde dağılımı, ortalama ve standart sapma gibi betimsel istatistik değerlerinden yararlanılmıştır. Artvin ilini ziyaret eden turistlerin Artvin gastronomisi ile ilgili deneyimleri ilgili bulgular Likert ölçeğine göre aritmetik ortalamaların değerlendirme aralığı için Aralık Genişliği=(Dizi Genişliği)/(Yapılacak Grup Sayısı) formülünden yararlanılarak, beşli Likert ölçeğinin aralık genişliği 0.80 (5$1=4=4 / 5=0.80$ ) bulunmuştur (Özdamar, 2003). Son olarak ise Artvin ilini ziyaret eden turistlerin cinsiyet, uyruk, yaş, medeni durum, eğitim, meslek, gelir düzeyi, Artvin ilini tercih etme nedeni ve Artvin yemeklerini beğenme durumuna göre karşılaştırılması amacıyla verilerin normal dağılım gösterip göstermediğine ilişkin Skewness ve Kurtosis puanları dikkate alındığında ise değişkenlerin normal dağılım gösterdiği tespit edilmiştir. Bu kapsamda aritmetik ortalama, mod ve medyanın eşit ya da yakın olması, çarpıklık ve basıklık katsayılarının \pm 1 sınırları içinde 0 'a yakın olması, çarpıklık ve basıklık katsayılarının kendi standart hatalarına bölünmesi ile hesaplanan çarpıklık ve basıklık indekslerinin \pm 2 sınırları içinde 0 'a yakın olması, standart sapma ile ortalamanın oranını yüzde olarak ifade eden bağıl değişim katsayısının 20 ile 25 arasında olması normal dağılımın varlığına kanıt olarak değerlendirilmektedir (Tabachnick ve Fidell, 2013). Bu nedenle Artvin ilini ziyaret eden turistlerin demografik özellikleri ve gastronomi deneyimleri ile ilgili verilerin normal dağılım gösterdiği ve araştırmanın amacına uygun olarak hazırlanmış olan hipotezleri test etmek için Bağımsız Örneklem T Testi (Independent-Samples T Test) ve Tek Faktörlü Varyans Analizi (One Way Anova) testlerine başvurulmuş olup farklılaşan grupları tespit etmek için de tamamlayıcı Post-Hoc analiz tekniğinden yararlanılmıştır (Büyüköztürk vd., 2009).

\section{BULGULAR}

\section{Yiyecek İçecek Hizmeti Satın Alan Turistlerin Demografik Özellikleri}

Artvin ilinde yiyecek içecek hizmeti satın alan turistlerin demografik özelliklerinden cinsiyet, uyruk, yaş, medeni durum, eğitim, meslek, gelir düzeyi, Artvin'i tercih etme nedeni ve Artvin yemeklerini beğenme durumu bilgilerine Tablo 1'de yer verilmektedir.

Tablo 1. Araştırmaya katılan turistlerin demografik özellikleri

\begin{tabular}{lllll}
\hline \multirow{2}{*}{ Cinsiyet } & & $\mathrm{f}$ & $\%$ & s.s. \\
\hline \multirow{2}{*}{ Uyruğunuz } & Kadın & 175 & 43,8 & \multirow{2}{*}{, 496} \\
\cline { 2 - 4 } & Erkek & 225 & 56,2 \\
\hline \multirow{2}{*}{ Yaş } & Yerli & 332 & 83,0 \\
\cline { 2 - 4 } & Yabanc1 & 68 & 17,0 \\
\hline
\end{tabular}


Yener Oğan, Fügen Durlu Özkaya 5(2) 2021

Güncel Turizm Araştırmaları Dergisi

\begin{tabular}{|c|c|c|c|c|}
\hline & 30-35 yaş & 82 & 20,5 & \\
\hline & 36-41 yaş & 32 & 8,0 & \\
\hline & $42-47$ yaş & 25 & 6,2 & \\
\hline & $48-53$ yaş & 20 & 5,0 & \\
\hline & $54-59$ yaş & 27 & 6,8 & \\
\hline & 60 ve üzeri & 14 & 3,5 & \\
\hline \multirow{2}{*}{ Medeni Durum } & Bekar & 209 & 52,2 & \multirow{2}{*}{, 500} \\
\hline & Evli & 191 & 47,8 & \\
\hline \multirow{5}{*}{ Eğitim Durumu } & Okur Yazar Değil & 4 & 1,0 & \multirow{5}{*}{880} \\
\hline & İlkokul & 19 & 4,8 & \\
\hline & Ortaokul & 25 & 6,2 & \\
\hline & Lise & 108 & 27,0 & \\
\hline & Üniversite & 244 & 61,0 & \\
\hline \multirow{5}{*}{ Mesleki Durum } & Özel Sektör & 158 & 39,5 & \multirow{5}{*}{1,879} \\
\hline & Kamu Sektörü & 84 & 21,0 & \\
\hline & Emekli & 38 & 9,5 & \\
\hline & Öğrenci & 71 & 17,8 & \\
\hline & Çalışmıyor & 49 & 12,2 & \\
\hline \multirow{4}{*}{ Gelir Düzeyi } & 2000 TL ve altı & 145 & 36,2 & \multirow{4}{*}{1,004} \\
\hline & $2000-4000 \mathrm{TL}$ & 141 & 35,2 & \\
\hline & $4001-6000 \mathrm{TL}$ & 66 & 16,5 & \\
\hline & 6001 ve üzeri & 48 & 12,0 & \\
\hline \multirow{11}{*}{$\begin{array}{l}\text { Artvin İlinizi Ziyaret Etmenizde En Etkili } \\
\text { Özellik }\end{array}$} & Doğa & 263 & 65,8 & \multirow{11}{*}{2,775} \\
\hline & Kültür & 43 & 10,8 & \\
\hline & Konaklama & 15 & 3,8 & \\
\hline & $\begin{array}{l}\text { Yemek } \\
\text { (Gastronomi) }\end{array}$ & 13 & 3,2 & \\
\hline & Mimari & 10 & 2,5 & \\
\hline & Sosyal Yaşam & 10 & 2,5 & \\
\hline & Ulaşım & 6 & 1,5 & \\
\hline & Hava Şartları & 7 & 1,8 & \\
\hline & Ekonomik & 8 & 2,0 & \\
\hline & $\overline{\text { İş }}$ & 14 & 3,5 & \\
\hline & Diğer & 11 & 2,8 & \\
\hline \multirow{2}{*}{ Artvin'e Özgü Yemekleri Beğenme Durumu } & Evet & 328 & 82,0 & \multirow{2}{*}{,384 } \\
\hline & Hayır & 72 & 18,0 & \\
\hline Toplam & & 400 & 100 & \\
\hline
\end{tabular}


Tablo 1'de turistlerin demografik özelliklere ilişkin bulgular incelendiğinde turistlerin cinsiyet değişkenine göre \%43,8'inin kadın, \%56,2'sinin erkek olduğu görülmektedir. Turistlerin uyrukları incelendiğinde ise \%83'ünü yerli turistler ve \%17'sini yabanc1 turistler oluşturmaktadır. Dolayısıyla turistlerin cinsiyet dağılımı birbirine yakın olmasına rağmen yerli turistler, yabancı turistlere oranla yöreyi daha fazla tercih etmektedir. Yaş aralığına bakıldığında turistlerin \%21,2'si 18-23, \%28,8' i 24-29, \%20,5'i 30-35, \%8,0'i 36-41, \%6,2'si 42-47, \%5,0'i 48-53, \%6,8'i 54-59 ve \%3,5'i ise 60 ve üstü yaş aralığında olduğu görülmektedir. Bu doğrultuda araştırmaya katılan turistlerin \%70,5 gibi büyük bir bölümü 35 yaş ve altı bireyler oluşturmaktadır.

Turistlerin medeni durumları incelendiğinde \%52,2'sinin bekar ve \%47,8'inin evli olduğu tespit edilmiştir. Turistlerin eğitim düzeylerine bakıldığında ise \%4,8'i ilkokul, \%6,2'si ortaokul, \%27,0'si lise, \%61,0'i üniversite ve \%4,0'ü okuryazar olmadı̆̆ tespit edilmiştir. Dolayısıyla turistlerin medeni durumları birbirine yakın dağılmakta olup, turistlerin büyük bir bölümü yükseköğretim düzeyinde bireylerden oluşmaktadır. Turistlerin meslek grupları incelendiğinde \%39,5'i özel sektör, \%21,0'i kamu sektörü, \%9,5'i emekli, \%17,8'i emekli ve \%12,2'si çalışmayan turistler oluşturmaktadır. Turistlerin gelir düzeyleri incelendiğinde ise \%36,2'si 2000TL ve altı, \%35,2'si 20014000TL, \%16,5'i 4001-6000TL ve \%12,0'si 6000TL ve üstü olduğu görülmektedir. Dolayısıyla turistlerin büyük bir bölümü aktif olarak çalıştığı ve ortalama bir gelir düzeyinin olduğu ifade edilebilmektedir.

Turistlerin Artvin ilini ziyaret etmelerinde en önemli tercih nedenleri \%65,8'i doğa, \%10,8'i kültür, \%3,8'i gastronomi, \%2,5'i mimari, \%2,5'i sosyal yaşam, \%1,5'i ulaşım, \%1,8'i hava şartları, \%2,0'si ekonomik, \%3,5'i iş ve \%2,8'i diğer nedenler (aile, eğitim vb.) olduğu tespit edilmiştir. Bu durum yörenin turizm çekiciliğinde doğal kaynakların etkili olduğu şeklinde yorumlanabilmektedir. Son olarak turistlerin Artvin'e özgü yemekleri beğenme durumu incelendiğinde \%82,0'si evet ve \%18,0'i hayır olduğu tespit edilmiş olup, yöreyi ziyaret eden turistlerin yöresel yemekler ile ilgili olumlu düşünceleri bulunmaktadır.

\section{Yiyecek İçecek Hizmeti Satın Alan Turistlerin Artvin Gastronomisi Deneyimleri}

Artvin ilinde yiyecek içecek hizmeti satın alan turistlerin Artvin gastronomi deneyimlerine ilişkin görüşleri ile ilgili yüzde, ortalama ve standart sapma değerlerine Tablo 2'de yer verilmektedir. 
Tablo 2. Araştırmaya katılan turistlerin Artvin gastronomisi deneyimleri ile ilgili görüşleri

\begin{tabular}{|c|c|c|c|c|c|c|c|c|}
\hline & \multirow[b]{2}{*}{ Turistlerin Gastronomi Deneyimleri } & \multicolumn{5}{|c|}{$\%(n=400)$} & \multirow[b]{2}{*}{$\bar{x}$} & \multirow[b]{2}{*}{ s.s. } \\
\hline & & 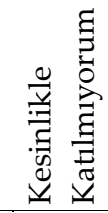 & 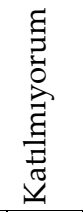 & 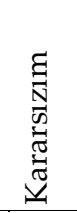 & 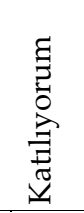 & 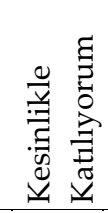 & & \\
\hline 1 & $\begin{array}{l}\text { Artvin'i ziyaret etmemde yöresel mutfak kültürü benim için önemli bir } \\
\text { etkendir. }\end{array}$ & 10,5 & 15,5 & 32,2 & 19,2 & 22,5 & 3,27 & 1,262 \\
\hline 2 & Artvin yöresinin zengin bir gastronomisi bulunmaktadır. & 8,2 & 16,8 & 31,2 & 26,5 & 17,2 & 3,27 & 1,174 \\
\hline 3 & Artvin yöresinin yemek kültürüyle ilgili bilgi sahibiyim. & 6,0 & 25,8 & 26,5 & 26,2 & 15,5 & 3,19 & 1,159 \\
\hline 4 & Artvin yöresine ait yemekleri tatma fırsatı buldum. & 3,2 & 15,8 & 27,2 & 28,0 & 25,8 & 3,57 & 1,128 \\
\hline 5 & Artvin yöresine ait çok çeşitli lezzetler bulunmaktadır. & 2,8 & 15,0 & 29,5 & 31,8 & 21,0 & 3,53 & 1,066 \\
\hline 6 & Artvin yöresine ait yemekler besleyici özelliğe sahiptir. & 5,0 & 8,5 & 25,5 & 34,8 & 26,2 & 3,68 & 1,101 \\
\hline 7 & Artvin yöresine ait yemekler doyurucudur. & 4,0 & 10,2 & 23,5 & 38,0 & 24,2 & 3,68 & 1,072 \\
\hline 8 & Artvin yöresine ait yemekler sağlık açısından yararlıdır. & 4,2 & 7,5 & 31,5 & 35,2 & 21,5 & 3,62 & 1,035 \\
\hline 9 & Artvin ilinde yeterli sayıda yiyecek içecek işletmesi bulunmaktadır. & 8,5 & 15,8 & 30,0 & 28,5 & 17,2 & 3,30 & 1,176 \\
\hline 10 & $\begin{array}{l}\text { Artvin'deki yiy. iç. işletmeleri yöre yemekleri hakkında yeterli bilgiye } \\
\text { sahiptir. }\end{array}$ & 6,2 & 19,8 & 32,2 & 26,0 & 15,8 & 3,25 & 1,130 \\
\hline 11 & $\begin{array}{l}\text { Yiy. iç. işletmeleri menülerinde yöre yemeklerini yeterli ölçüde } \\
\text { kullanmaktadır }\end{array}$ & 6,8 & 22,5 & 30,8 & 27,5 & 12,5 & 3,16 & 1,116 \\
\hline 12 & $\begin{array}{l}\text { Yiyecek içecek işletmeleri menülerinde yöre yemeklerinin fiyatları } \\
\text { uygundur. }\end{array}$ & 19,5 & 19,0 & 31,0 & 26,8 & 13,8 & 3,16 & 1,168 \\
\hline 13 & $\begin{array}{l}\text { Yiy. iç. işletmelerinde yöre yemekleri lezzetli fakat sunumları yeterli } \\
\text { değildir. }\end{array}$ & i 10,8 & 19,5 & 31,8 & 26,2 & 11,8 & 3,08 & 1,163 \\
\hline 14 & $\begin{array}{l}\text { Yiyecek içecek işletmelerinde yöre yemekleri yöreye özgü servis } \\
\text { edilmektedir. }\end{array}$ & 8,2 & 20,2 & 31,5 & 25,5 & 14,5 & 3,17 & 1,157 \\
\hline 15 & Yiyecek içecek işletmeleri yöre yemeklerine daha fazla önem vermelidir. & 7,0 & 9,8 & 24,2 & 26,5 & 32,5 & 3,67 & 1,219 \\
\hline 16 & Artvin'e özgü yöresel yiyecek ve içecekleri satın almak isterim. & 5,8 & 12,8 & 20,8 & 32,9 & 28,0 & 3,64 & 1,180 \\
\hline 17 & $\begin{array}{l}\text { Yöresel yiyecek ve içeceklerin tanıtım ve pazarlama faaliyetleri } \\
\text { yeterlidir. }\end{array}$ & $i_{9,5}$ & 20,2 & 29,0 & 28,2 & 13,0 & 3,15 & 1,168 \\
\hline 18 & $\begin{array}{l}\text { Artvin'e özgü yiyecek ve içeceklerin tanıtılması, bölge gelişimine katkı } \\
\text { sağlar. }\end{array}$ & 5,0 & 9,2 & 24,8 & 29,0 & 32,0 & 3,73 & 1,149 \\
\hline 19 & $\begin{array}{l}\text { Yöresel yemeklerini deneyimlemek için Artvin iline tekrar gelmek } \\
\text { isterim. }\end{array}$ & 6,2 & 13,5 & 22,8 & 24,2 & 33,2 & 3,64 & 1,241 \\
\hline 20 & Artvin ilini ve yemeklerini çevreme (arkadaş/akraba) tavsiye ederim. & 6,0 & 4,5 & 17,0 & 26,2 & 46,2 & 4,02 & 1,164 \\
\hline
\end{tabular}

Tablo 2'deki araştırmaya katılan Artvin ilinde yiyecek içecek hizmeti satın alan turistlerin Artvin gastronomi deneyimlerine ilişkin görüşleri incelendiğinde; 
"Artvin ilini ve yemeklerini çevreme (arkadaş/akraba) tavsiye ederim." $\quad(\bar{x}=4,02)$ ifadesine en yüksek ortalama ile cevap verdikleri görülmektedir. Bu durum turistlerin Artvin ili ve yöre yemekleri ile ilgili genel olarak olumlu düşüncelere sahip olduğu şeklinde yorumlanabilmektedir.

"Artvin'e özgü yiyecek ve içeceklerin tanıtılması, bölge gelişimine katkı sağlar." $\left(x^{-}=3,73\right)$, "Artvin yöresine ait yemekler besleyici özelliğe sahiptir." ve "Artvin yöresine ait yemekler doyurucudur." ( $\overline{x=3,68), ~ " Y i y e c e k ~ i c ̧ e c e k ~ i s ̧ l e t m e l e r i ~ y o ̈ r e ~ y e m e k l e r i n e ~}$ daha fazla önem vermelidir." ( $\overline{x=3,67), ~ " A r t v i n ' e ~ o ̈ z g u ̈ ~ y o ̈ r e s e l ~ y i y e c e k ~ v e ~ i c ̧ e c e k l e r i ~}$ satın almak isterim." ve "Yöresel yemeklerini deneyimlemek için Artvin iline tekrar gelmek isterim." ( $\overline{x=3,64), ~ " A r t v i n ~ y o ̈ r e s i n e ~ a i t ~ y e m e k l e r ~ s a g ̆ l ı k ~ a c ̧ ı s ı n d a n ~ y a r a r l ı d ı r . " ~}$ $(\bar{x}=3,62)$, "Artvin yöresine ait yemekleri tatma firsatı buldum." ( $\overline{x=3,57), ~ " A r t v i n ~}$ yöresine ait çok çeşitli lezzetler bulunmaktadır." ( $\overline{x=3,53)}$ ifadelerine yüksek ortalama ile cevap verdikleri görülmektedir. Bu ifadelerden hareketle turistlerin Artvin yemeklerini besleyici, doyurucu, sağlıklı, lezzetli bulduğu şeklinde yorumlamak mümkündür. Ayrıca gastronomi deneyimi ile ilgili benzer çalışmalarda turistlerin yöreye özgü yemekleri deneyimlemek istediği, yöreyi tekrar ziyaret etmede yöresel yemeklerin önemli olduğu ve destinasyon tercihlerinde yöresel yiyeceklerin kültürel kimliğin önemli bir unsuru olduğu ifade edilmiştir. Yöresel yemeklerin gastronomi turizmi amaçlı kullanılmasıyla yöreye önemli katkı sunacağı düşünüldüğünde ise yöreye özgü yemeklerin turistlerin gastronomi deneyimleri açısından önemli bir yeri bulunmaktadır (Kivela ve Crotts, 2006; Jang ve Feng, 2007; Canizares ve Guzman, 2012; Birdir ve Akgöl, 2015; Çapar ve Yenipınar, 2016).

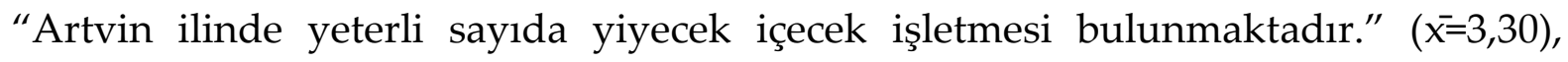
"Artvin'i ziyaret etmemde yöresel mutfak kültürü benim için önemli bir etkendir." ve "Artvin yöresinin zengin bir gastronomisi bulunmaktadır." ( $\overline{x=3,27), ~ " A r t v i n ' d e k i ~}$

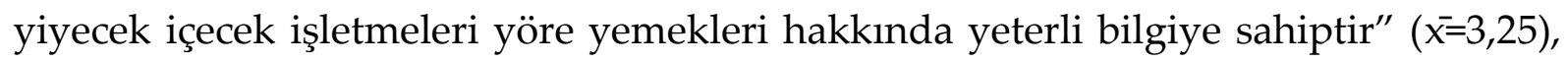
"Artvin yöresinin yemek kültürüyle ilgili bilgi sahibiyim." $(\bar{x}=3,19)$, "Yiyecek içecek işletmelerinde yöre yemekleri yöreye özgü servis edilmektedir." ( $\overline{x=3,17), ~ " Y i y e c e k ~}$ içecek işletmeleri menülerinde yöre yemeklerini yeterli ölçüde kullanmaktadır" ve "Yiyecek içecek işletmeleri menülerinde yöre yemeklerinin fiyatları uygundur." $(\bar{x}=3,16)$, "Yöresel yiyecek ve içeceklerin tanıtım ve pazarlama faaliyetleri yeterlidir." $\left(x^{-}=3,15\right)$, "Yiyecek içecek işletmelerinde yöre yemekleri lezzetli fakat sunumları yeterli değildir." $(\overline{x=3,08)}$ ifadelerine orta düzeyde bir ortalama ile cevap verdikleri görülmektedir. Turistlerin ziyaret ettiği destinasyonda yiyecek içecek ile ilgili beklenti düzeyinin yüksek olduğu ve gastronomik davranışlarında farklılıklar gösterdiği ilgili çalışmalarda belirtilmiştir (Correia vd., 2007; Chang vd., 2010). Ayrıca turistlerin yiyecek ve içeceklere yönelik tutum, öznel normlar, algılanan davranışsal kontrol ve geçmiş deneyimlerin önemli olduğu ortaya konulmuştur (Chavarria ve PhakdeeAuksorn, 2017). Dolayısıyla turistler Artvin ilinde yiyecek içecek işletmelerinin sayısı, donanımı, yemek ücretleri, hizmet kalitesi, servis şekilleri, pazarlama faaliyetleri gibi özellikleri yeterli düzeyde bulmadığı ve turistlerin yöre mutfak kültürü hakkında bilgi düzeyinin kısmen olduğu şeklinde yorumlanabilmektedir. Bu bağlamda "Artvin 
ilinde yiyecek içecek hizmeti satın alan turistlerin Artvin ili gastronomisi ile ilgili deneyimleri bulunmaktadır" hipotezi (H1) kabul edilmiştir.

\section{Artvin Gastronomi Deneyimleri ile Turistlerin Cinsiyet, Uyruk, Medeni Durum ve} Yemekleri Beğenme Durumuna Göre T-Testi Analizi

Artvin ilinde yiyecek içecek hizmeti satın alan turistlerin Artvin gastronomisi deneyimleri görüşlerinin cinsiyet, uyruk, medeni durum ve yemekleri beğenme durumu arasında anlamlı bir farklılık gösterip göstermediğini belirlemek amacıyla yapılan T-testi sonuçlarına ilişkin bulgulara Tablo 3'te yer verilmektedir.

Tablo 3. Turistlerin cinsiyet, uyruk, medeni durum ve yemekleri beğenme durumu ile Artvin gastronomisi deneyimleri arasındaki t-testi sonuçları

\begin{tabular}{|c|c|c|c|c|c|c|c|c|}
\hline Faktör & & Cinsiyet & $\mathrm{n}$ & $\bar{x}$ & s.s. & $\mathrm{t}$ & $\mathrm{Sd}$ & $\mathrm{p}$ \\
\hline \multirow{2}{*}{$\begin{array}{l}\text { Artvin Gastronomisi } \\
\text { Toplam Puanı }\end{array}$} & \multirow{2}{*}{ Deneyimleri } & Kadın & 175 & 3,378 & ,763 & \multirow{2}{*}{4,326} & \multirow{2}{*}{398} & \multirow{2}{*}{038} \\
\hline & & Erkek & 225 & 3,494 & 682 & & & \\
\hline & & Uyruk & & & & & & \\
\hline \multirow{2}{*}{$\begin{array}{l}\text { Artvin Gastronomisi } \\
\text { Toplam Puanı }\end{array}$} & \multirow{2}{*}{ Deneyimleri } & Yerli & 332 & 3,403 & 758 & \multirow{2}{*}{22,823} & \multirow{2}{*}{398} & \multirow{2}{*}{,000 } \\
\hline & & Yabanc1 & 68 & 3,641 & 444 & & & \\
\hline & & Medeni & & & & & & \\
\hline \multirow{2}{*}{$\begin{array}{l}\text { Artvin Gastronomisi } \\
\text { Toplam Puanı }\end{array}$} & \multirow[t]{2}{*}{ Deneyimleri } & Bekar & 209 & 3,441 & 677 & \multirow{2}{*}{6,470} & \multirow{2}{*}{398} & \multirow{2}{*}{011} \\
\hline & & Evli & 191 & 3,446 & 766 & & & \\
\hline \multicolumn{9}{|l|}{ Yemekleri Beğenme } \\
\hline \multirow{2}{*}{$\begin{array}{l}\text { Artvin Gastronomisi } \\
\text { Toplam Puanı }\end{array}$} & \multirow[t]{2}{*}{ Deneyimleri } & Evet & 328 & 3,611 & 620 & \multirow{2}{*}{,019 } & \multirow{2}{*}{398} & \multirow{2}{*}{891} \\
\hline & & Hayır & 72 & 2,679 & 647 & & & \\
\hline Toplam & & & 400 & & & & & \\
\hline
\end{tabular}

Tablo 3'te yer alan cinsiyet, uyruk, medeni durum ve yemekleri beğenme durumu ile ilgili T-testi sonuçları incelendiğinde;

Artvin ilinde yiyecek içecek hizmeti satın alan turistlerin Artvin gastronomisi deneyimleri görüşleri cinsiyete göre anlamlı bir farklılık göstermektedir. $[t(4,326)=398$, $\mathrm{p}<.05]$. Dolayısıyla kadın turistlerin görüşleri ile erkek turistlerin gastronomi deneyimleri farkl1laşmakta olup, bu durum cinsiyet değişkenine göre düşünce, izlenim ve tutum farklılıklarından kaynaklandığı şeklinde açıklanabilmektedir.

Artvin ilinde yiyecek içecek hizmeti satın alan turistlerin Artvin gastronomisi deneyimleri görüşleri uyruğa göre anlamlı bir farklılık göstermektedir. $[t(22,823)=398$, $\mathrm{p}<$.05]. Yerli turistlerin yöreyi seyahat etme tercihleri ve yöredeki yiyecek içecek beklentileri ile ilgili anlamlı sonuçlara ulaşılması da bu durumu desteklemektedir (Ayaz ve Yalı, 2017). Dolayısıyla yerli turistler ile yabancı turistlerin gastronomi deneyimleri farklilaşmakta olup, bu durum sebebi ise yerli turistlerin yabanc1 turistlere göre yöreyi daha iyi bilmeleri ve beklenti düzeyinin yüksek olması şeklinde yorumlanabilmektedir. 
Artvin ilinde yiyecek içecek hizmeti satın alan turistlerin Artvin gastronomisi deneyimleri görüşleri medeni duruma göre anlamlı bir farklılık göstermektedir. $[\mathrm{t}(6,470)=398, \mathrm{p}<.05]$. Dolayısıyla bekar turistler ile evli turistlerin gastronomi deneyimleri ile ilgili görüşleri farklılaşmakta olup, bu durumun kaynağı evli turistlerin bekar turistlere göre beklenti düzeyinin yüksek olması şeklinde açıklanabilmektedir.

Artvin ilinde yiyecek içecek hizmeti satın alan turistlerin Artvin gastronomisi deneyimleri görüşleri yemekleri beğenme duruma göre anlamlı bir farklılık göstermemektedir. [t(,019)=398, p>.05]. Bu bağlamda Artvin ili gastronomisi deneyimleri ile Artvin ilinde yiyecek içecek hizmeti satın alan turistlerin demografik özellikleri arasında cinsiyet, uyruk ve medeni durum (H2.1, H2.2 ve H2.4) ile ilgili hipotezler kabul edilmiş olup, yemekleri beğenme durumu (H2.9) hipotezi ise kabul edilmemiştir.

\section{Artvin Gastronomisi Deneyimleri ile Turistlerin Yaş, Eğitim, Meslek, Gelir ve} Artvin'i Tercih Etme Nedeni ile İlgili Tek Faktörlü Varyans Analizi

Artvin ilinde yiyecek içecek hizmeti satın alan turistlerin Artvin gastronomisi deneyimleri görüşlerinin yaş grubu, eğitim düzeyi, mesleki durumu, gelir seviyesi ve Artvin'i tercih etme nedenine göre karşılaştırması amacı ile ilişkisiz ölçümler için Tek Faktörlü Varyans Analizi uygulanmış ve sonuçlarına Tablo 4'te yer verilmektedir.

Tablo 4. Turistlerin Artvin gastronomi deneyimlerinin yaş grubu, eğitim düzeyi, mesleki durumu, gelir seviyesi ve Artvin'i tercih etme nedenine göre karşılaştırılması ile ilgili tek faktörlü varyans analizi sonuçları (anova)

\begin{tabular}{|c|c|c|c|c|c|c|}
\hline Yaş Grubu & $\begin{array}{l}\text { Varyansın } \\
\text { Kaynağ }\end{array}$ & $\begin{array}{l}\text { Kareler } \\
\text { Toplamı }\end{array}$ & $\mathrm{Sd}$ & $\begin{array}{l}\text { Kareler } \\
\text { Ortalaması }\end{array}$ & $\mathrm{F}$ & $\mathrm{p}$ \\
\hline \multirow{2}{*}{$\begin{array}{l}\text { Artvin Gastronomisi } \\
\text { Deneyimleri Toplam Puanı }\end{array}$} & Gruplar arası & 8,160 & 7 & 1,166 & 2,299 & ,026 \\
\hline & Gruplar içi & 198,780 & 392 & ,507 & & \\
\hline \multicolumn{7}{|l|}{ Eğitim Düzeyi } \\
\hline \multirow{2}{*}{$\begin{array}{l}\text { Artvin } \quad \text { Gastronomisi } \\
\text { Deneyimleri Toplam Puanı }\end{array}$} & Gruplar arası & 5,412 & 4 & 1,353 & 2,652 & ,033 \\
\hline & Gruplar içi & 201,527 & 395 & ,510 & & \\
\hline \multicolumn{7}{|l|}{ Mesleki Durum } \\
\hline \multirow{2}{*}{$\begin{array}{l}\text { Artvin } \quad \text { Gastronomisi } \\
\text { Deneyimleri Toplam Puanı }\end{array}$} & Gruplar arası & 5,820 & 4 & 1,455 & 2,857 & ,023 \\
\hline & Gruplar içi & 201,120 & 395 & ,509 & & \\
\hline \multicolumn{7}{|l|}{ Gelir Seviyesi } \\
\hline \multirow{2}{*}{$\begin{array}{l}\text { Artvin Gastronomisi } \\
\text { Deneyimleri Toplam Puanı }\end{array}$} & Gruplar arası & 1,535 & 3 & ,512 & ,987 & ,399 \\
\hline & Gruplar içi & 205,404 & 396 & ,519 & & \\
\hline \multicolumn{7}{|l|}{ Artvin Tercih Nedeni } \\
\hline \multirow{2}{*}{$\begin{array}{l}\text { Artvin } \quad \text { Gastronomisi } \\
\text { Deneyimleri Toplam Puanı }\end{array}$} & Gruplar arası & 18,787 & 10 & 1,879 & 3,884 & ,000 \\
\hline & Gruplar içi & 1883152 & 389 & ,484 & & \\
\hline Toplam & & 206,939 & 399 & & & \\
\hline
\end{tabular}


Tablo 4'te yer alan yaş grubu, eğitim düzeyi, mesleki durumu, gelir seviyesi ve Artvin'i tercih etme nedeni ile ilgili Tek Faktörlü Varyans Analizi sonuçları incelendiğinde;

Artvin ilinde yiyecek içecek hizmeti satın alan turistlerin yaş grupları ile Artvin gastronomisi deneyimleri toplam puanları arasında anlamlı bir fark olduğu görülmektedir $\mathrm{F}(7,392)=2,299, \mathrm{p}<, 05$. Diğer bir ifadeyle turistlerin Artvin gastronomisi ile ilgili görüşleri yaşlarına bağlı olarak değişmektedir. Artvin ilinde yiyecek içecek hizmeti satın alan turistlerin eğitim durumları ile Artvin gastronomisi deneyimleri toplam puanları arasında anlamlı bir fark olduğu görülmektedir $F(4,395)=2,652$, $\mathrm{p}<, 05$. Diğer bir ifadeyle turistlerin Artvin gastronomisi ile ilgili görüşleri eğitim durumuna bağlı olarak değişmektedir. Artvin ilinde yiyecek içecek hizmeti satın alan turistlerin mesleki durumları ile Artvin gastronomisi deneyimleri toplam puanlar1 arasında anlamlı bir fark olduğu görülmektedir $F(4,395)=1,455, p<, 05$. Diğer bir ifadeyle turistlerin Artvin gastronomisi ile ilgili görüşleri mesleki durumuna bağl1 olarak değişmektedir. Artvin ilinde yiyecek içecek hizmeti satın alan turistlerin gelir düzeyleri ile Artvin gastronomisi deneyimleri toplam puanları arasında anlamlı bir fark olduğu görülmemektedir $F(3,396)=, 512, p>, 05$. Diğger bir ifadeyle turistlerin Artvin gastronomisi ile ilgili görüşleri gelir düzeyine bağlı olarak değişmemektedir. Artvin ilinde yiyecek içecek hizmeti satın alan turistlerin Artvin ilini tercih etme durumu ile Artvin gastronomisi deneyimleri toplam puanları arasında anlamlı bir fark olduğu görülmektedir $\mathrm{F}(10,389)=1,4879, \mathrm{p}<, 05$. Zağralı ve Akbaba (2015) çalışmalarında belirttiği üzere turistlerin İzmir Yarımadası'nı ziyaret tercihinde yöresel yemeklerin belirleyici olmadığ gastronomisi ile ilgili görüşleri destinasyonu tercih etme durumuna bağlı olarak değişmektedir. Bu bağlamda yapılan analizler doğrultusunda turistlerin Artvin gastronomi deneyimlerinin hangi gruplarda farklılaştığ 1 ile ilgili Post-Hoc Tukey testi sonuçları Tablo 5'te yer almaktadır.

Tablo 5. Artvin ilinde yiyecek içecek hizmeti satın alan turistlerin Artvin gastronomi deneyimlerinin hangi gruplarda farklılaştığı ile ilgili post-hoc tukey testi sonuçları

\begin{tabular}{|c|c|c|c|c|c|c|c|c|c|}
\hline Gruplar & & $\begin{array}{l}\text { Değişkenler } \\
\text { (j) }\end{array}$ & $\mathrm{n}$ & $\bar{x}$ & $\begin{array}{l}\text { Levene } \\
\text { Testi }\end{array}$ & S.s. & $\begin{array}{l}\text { Ortalamalar Arası } \\
\text { Fark (İ-J) }\end{array}$ & S.hata & P (Sig.) \\
\hline $\begin{array}{l}\text { Yaş } \\
\text { Grubu }\end{array}$ & 30-35 yaş & 18-23 yaş & 82 & 3,67 & 1,401 & 695 & ,33792* & ,11023 & ,047 \\
\hline $\begin{array}{l}\text { Eğitim } \\
\text { Seviyesi }\end{array}$ & Üniversite & Lise & 244 & 3,53 & 4,385 & 679 & ,26350* & ,08144 & ,014 \\
\hline $\begin{array}{l}\text { Mesleki } \\
\text { Durum }\end{array}$ & Öğrenci & Özel Sektör & 71 & 3,66 & 1,033 & ,791 & ,32558* & 10195 & ,013 \\
\hline \multirow{5}{*}{$\begin{array}{l}\text { Artvin'i } \\
\text { Tercih } \\
\text { Nedeni }\end{array}$} & \multirow{2}{*}{ Yemek } & Kültür & \multirow{2}{*}{13} & \multirow{2}{*}{4,15} & & \multirow{2}{*}{604} &, $88175^{*}$ & ,19228 & ,010 \\
\hline & & Konaklama & & & & & $1,24385^{*}$ & ,23158 & ,001 \\
\hline & \multirow{3}{*}{$\begin{array}{l}\text { Hava } \\
\text { Şartları }\end{array}$} & Doğa & & & 2,125 & & $34221^{*}$ & ,07748 & ,042 \\
\hline & & Kültür & 7 & 3,80 & & 170 & ,52791* & 11409 & ,003 \\
\hline & & Konaklama & & & & & ,89000* & 17225 & ,004 \\
\hline
\end{tabular}


Tablo 5'te yer alan Post-Hoc Tukey test sonuçları incelendiğinde 30-35 yaş grubu arasındaki turistlerin Artvin gastronomi deneyimleri 18-23 yaş grubunda yer alan turistlere göre lehine farklılaşmaktadır. Yine Tukey test sonuçlarına göre üniversite düzeyinde eğitim seviyesi olan turistlerin lise düzeyinde olan turistlere ve öğrenci olan turistlerin özel sektörde çalışan turistlere göre lehine farklılaştığı görülmektedir. Son olarak turistlerin Artvin ilini tercih etme nedeni olarak yemek tercihleri kültür ve konaklama, hava şartları ise doğa, kültür ve konaklama lehine farklılaşmaktadır. Bu bağlamda Artvin ili gastronomisi deneyimleri ile Artvin ilinde yiyecek içecek hizmeti satın alan turistlerin demografik özellikleri arasında yaş, eğitim, meslek ve Artvin'i tercih nedeni (H2.3, H2.5, H2.6 ve H2.8) ile ilgili hipotezler kabul edilmiş olup, gelir seviyesi hipotezi (H2.7) ise kabul edilmemiştir.

\section{SONUÇ, TARTIŞMA VE ÖNERİLER}

Bir destinasyonu ziyaret eden turistler dinlenmek, gezmek, görmek, eğlenmek gibi aktivitelerin yanı sıra gittikleri bölgedeki yöresel yemekleri tatma eğiliminde oldukları görülmektedir (Erdem vd., 2018). Özellikle turistlerin yöreye özgü yemekleri deneyimleme isteği, yöreyi tekrar ziyaret etmede yöresel yemeklerin önemli olması ve destinasyon tercihlerinde yöresel yiyeceklerin etkili olması, yöredeki yiyecek içecek konusunda beklentileri gibi pek çok etken yöresel yemeklerin gastronomi turizmi amaçlı kullanılması gerekliliğini oluşturmaktadır. Gastronomi turizmi açısından zengin bir potansiyeli bulunan Türkiye, sahip olduğu bu potansiyeli turizme yansıtmayı başarabilir ise turizm gelirinde önemli bir artış sağlaması da kaçınılmazdır (Öney, 2013). Artvin ili; yöresel ürünleri, yöreye özgü yemekleri, geleneksel ekipmanlar ve pişirme teknikleri, zengin mutfak kültürü ile önemli bir gastronomi potansiyeline sahiptir. Dolayısıyla Artvin ilinin sahip olduğu gastronomi değerleri ile gerek gastronomi turizmi gerekse bölgenin gelişmesinde katkı sağlayabilme düzeyinin yüksek olduğu ifade edilebilmektedir. Araştırma kapsamında Artvin'i ziyaret eden turistlerin yöre gastronomisi ile ilgili görüşlerinin önemli olduğu düşünülmektedir.

$\mathrm{Bu}$ araştırma, Artvin ilinde yiyecek içecek hizmeti satın alan turistlerin Artvin gastronomisi deneyimleri ile ilgili görüşlerinin incelenmesi amacıyla yapılmıştır. Yöreyi ziyaret eden turistlerin Artvin ili gastronomisi ile ilgili deneyimlerinin yüksek düzeyde olduğu tespit edilmiştir. Turistlerin yöreyi ziyaret etmesinde yemeklerin önemli bir yerinin bulunduğu, yöre yemeklerini beğendikleri, yörede satın aldıkları yiyecek ve içecek hizmetinden memnun olduğu ve yörede olumlu izlenimler edindiği sonuçlarına ulaşılmıştır. Ancak yöre gastronomisinin tanıtım, pazarlama, menü, servis gibi konularda eksiklikleri bulunmaktadır. Bu durumu benzer bir çalışmada ulaşılan turistlerin yaşadıkları yemek deneyimleri sonucunda yöresel yemekleri beğendiği ve yöresel yemekler konusunda tanitım eksikliğinin söz konusu olduğu sonucu da desteklemektedir (Zağralı ve Akbaba, 2015). Dolayısıyla turistlerin yöresellik temalı gastronomi deneyim motivasyonlarının yüksek düzeyde olduğunun benimsenmesi ve turistlerin gastronomi deneyimlerinde ürün, ilişki, faaliyet ve ortam gibi çeşitli 
temalara yönelik önem verilmesi gerektiği ifade edilebilmektedir (Akyürek ve Kutukız, 2020; Işkın, 2021).

Araştırmada, Artvin ilinde yiyecek içecek hizmeti satın alan turistlerin demografik özelliklerinden cinsiyet, uyruk, medeni durum, yaş, eğitim, meslek ve Artvin'i tercih nedeni ile anlamlı ilişkiler bulunmakta iken gelir ve yemekleri beğenme durumu ile ilgili anlamlı düzeyde farklılık bulunmamıştır. Araştırma kapsamında elde edilen sonuçlar doğrultusunda bazı öneriler ise şu şekilde sıralanabilmektedir. Turizm sezonunun kısa olduğu yörede gastronomi turizmi rotaları konusunda çalışmalar yapılarak turizm sezonu dışında faaliyetler artırılmalıdır. Yörede bulunan yiyecek içecek işletmelerinin nitelik ve hizmet olarak kendilerini geliştirmelidir. Yörenin gastronomisi ile ilgili yöre içinde ve yöre dışında bilinirliği arttırıcı faaliyetlere yer verilmedir. Yöreye gastronomisini yansıtan yiyecek içecek işletmeleri mutlaka desteklenmelidir. Yöresel temalı yeni işletmelerin açılması ile ilgili çalışmalar yapılmalıdır. Yöre gastronomisi ile ilgili kamu kuruluşları, sivil toplum kuruluşları, işletmeler, yerel halk gibi tüm paydaşların bir araya gelerek yörenin gastronomisini geliştirici etkinlikler gerçekleştirilebilir. Yöreyi ziyaret eden turistlerin yöre gastronomisi konusunda olumlu tecrübeler edinmeleri sağlanmalıdır. Yöredeki yiyecek içecek işletmelerinin yöreye özgü yemeklere menülerinde daha fazla yer vermesi gerekmektedir.

\section{Hakem Değerlendirmesi: Dış bağımsız.}

Teşekkür: Katkılarından dolayı hakemlere teşekkür ederiz.

Destek Bilgisi: Herhangi bir kurum ve/veya kuruluştan destek alınmamıştır.

Çıkar Çatışması: Yazarlar arasında çıkar çatışması yoktur.

Etik Onayı: Bu çalışmanın tüm hazırlanma süreçlerinde etik kurallara riayet edildiğini yazar(lar) beyan eder. Aksi bir durumun tespiti halinde Güncel Turizm Araştırmaları
Dergisi'nin hiçbir sorumluluğu olmayıp, tüm sorumluluk makale yazar(lar)ına aittir.

Bilgilendirilmiş Onam Formu: Tüm taraflar kendi rızaları ile çalışmaya dâhil olmuşlardır. Etik Kurul Onayı: Ankara Hacı Bayram Veli Üniversitesi Etik Komisyonundan 16.09.2019 tarih ve 12 sayılı toplantısı ile izin alınmıştır.

Araştırmacıların Katkı Oranı: Yazarlar çalışmaya eşit oranda katkı sağlamıştır.

Veri Kullanılabilirlik Beyanı: Araştırma verileri paylaşılmamıştır.

\section{KAYNAKÇA}

Akyürek S. ve Kutukız, D. (2020). Gastro Turistlerin Deneyimleri: Gastronomi Turları Kapsaminda Nitel Bir Araştırma. Journal of Tourism and Gastronomy Studies, 8 (4), 3319-3346.

Arlı, M. ve Nazik, H. (2001). Bilimsel Araştırmaya Giriş. Ankara: Gazi Kitabevi.

Ayaz, N. ve Yalı, S. (2017) Kültürel Turistlerin Seyahat Tercihleri ve Yiyecek-İçecek Beklentileri: Safranbolu Örneği. Türk Turizm Araştırmaları Dergisi, 1 (1), 43-61.

Beşirli, H. (2010). Yemek, Kültür ve Kimlik. Milli Folklor Dergisi, 22 (87), 159-169. 
Birdir, K. ve Akgöl, Y. (2015). Gastronomi Turizmi ve Türkiye'yi Ziyaret Eden Yabanc1 Turistlerin Gastronomi Deneyimlerinin Değerlendirilmesi. İşletme ve İktisat Çalışmaları Dergisi, 3 (2), 57-68.

Büyüköztürk, Ş. (2009). Sosyal Bilimler İçin Veri Analizi El Kitabı. Ankara: Pegem Akademi.

Büyüköztürk, Ş., Çakmak, E. K., Akgün, E.A., Karadeniz, Ş. ve Demirel, F. (2009). Bilimsel Araştırma Yöntemleri. Ankara: Pegem Akademi.

Canizares, S. M. S. ve Guzman, T. L. (2012). Gastronomy as a Tourism Resource: Profile of the Culinary Tourist. Current Issues in Tourism, 15 (3), 229-245.

Chang, R. C. Y., Kivela, J., ve Mak, A. H. N. (2010). Food Preferences of Chinese Tourists. Annals of Tourism Research, 37 (4), 989-1011.

Chavarria, L. C. T. ve Phakdee-Auksorn, P. (2017). Understanding İnternational Tourists: Attitudes Towards Street Food In Phuket, Thailand. Tourism Management Perspectives, 21, 66-73.

Correia, A., Valle, P. ve Moço, C. (2007). Modeling Motivations And Perceptions Of Portuguese Tourists. Journal of Business Research, 60, 76-80.

Çapar, G. ve Yenipınar, U. (2016). Somut Olmayan Kültürel Miras Kaynağı Olarak Yöresel Yiyeceklerin Turizm Endüstrisinde Kullanılması. Journal of Tourism and Gastronomy Studies, 4 (1), 100-115.

Erdem, Ö., Mızrak, M. ve Kemer A. K. (2018). Yöresel Yemeklerin Bölge Restoranlarında Kullanılma Durumu: Mengen Örneği. Uluslararası Türk Dünyası Turizm Araştırmaları Dergisi, 3 (1).

Eryilmaz, B. ve Zengin, B. (2014). Sosyal Medyada Konaklama İşletmelerine Yönelik Tüketici Yaklaşımları Üzerine Bir Araştırma. İşletme Bilimi Dergisi, 2 (1), 147-167.

Getz, D. (2000). Explore Wine Tourism: Management, Development And Destinations. Cognizant Communication Corporation, New York.

Jang, S. ve Feng, R. (2007). Temporal Destination Revisit Intention: The Effects Of Novelty Seeking And Satisfaction. Tourism Management, 28 (2), 580-590.

Işkın, M. (2021). Türkiye'nin Gastronomi Turizmi Göstergeleri ve Yerli Turistlerin Gastronomi Turizmine Katılım Durumları. Journal of Global Tourism and Technology Research, 2 (1), 26-34.

Karasar, N. (2002). Bilimsel Araştırma Yöntemleri. Ankara: Nobel Akademik Yayıncılık Eğitim Danışmanlık.

Kesici, M. (2012), Kırsal Turizme Olan Talepte Yöresel Yiyecek ve İçecek Kültürünün Rolü. KMÜ Sosyal ve Ekonomik Araştırmalar Dergisi, 14 (23), 33-37.

Kivela, J. ve Crotts, C. J. (2006).Tourism And Gastronomy: Gastronomy's Influence On How Tourists Experience A Destinastion. Journal of Hospitality and Tourism Research. 30 (3), 354-377.

Morgan M., Lugosi P. ve Ritchie, J. R. B. (2010). The Tourism And Leisure Experience: Consumer and Managerial Perspectives. Channel View, Bristol. 
Özdamar, K. (2003). Modern Bilimsel Araştırma Yöntemleri. Eskişehir: Kaan Kitabevi.

Semerci, H. ve Akbaba, A. (2018). Bodrum'a Gelen Uluslararası Ziyaretçilerin Yerel Yemek Tüketimindeki Motivasyon Faktörlerinin Değerlendirilmesi. International Journal of Contemporary Tourism Research, 2 (1), 41-57

Serçek, (2018). Turistlerin Yerel Yemek Tüketimindeki Motivasyon Faktörlerinin İncelenmesi. Journal of Tourism and Gastronomy Studies, 6 (4), 463-481.

Tabachnick, B. G. ve Fidell, L. S. (2013). Using Multivariate Statistics. Pearson Education, USA.

Yamane, T. (2001). Temel Örnekleme Yöntemleri. İstanbul: Litaretür Yayınları.

Yazıcıŏ̆lu, Y. ve Erdoğan, S. (2004). Spss Uygulamalı Bilimsel Araştırma Yöntemleri. Ankara: Detay Anatolia Akademik Yayıncllık.

Yüncü, H. (2010). Sürdürülebilir Turizm Açısından Gastronomi Turizmi ve Perşembe Yaylası. X. Aybastı-Kabataş Kurultayı: 28-34.

Zağralı, E. ve Akbaba, A. (2015). Turistlerin Destinasyon Seçiminde Yöresel Yemeklerin Rolü: İzmir Yarımadası'nı Ziyaret Eden Turistlerin Görüşleri Üzerine Bir Araştırma. Journal of Yaşar University, 10 (40), 6633-6644. 